\title{
ПЕРВОЕ МИКОТОКСИКОЛОГИЧЕСКОЕ ИССЛЕДОВАНИЕ ГОРЧИЦЫ БЕЛОЙ (Sinapis alba L.)
}

\author{
А.А. БУРКИН 1 , Г.П. КОНОНЕНКО 1 , Л.В. МОСИНА ${ }^{2}$
}

Сельскохозяйственные культуры, широко представленные как на возделываемых угодьях, так и в естественных ботанических формациях, привлекают все большее внимание исследователей. Это связано с хозяйственной значимостью и высокой ценностью таких растений как экспериментальных объектов. Согласно современным представлениям, комплекс вторичных веществ в растениях рассматривается как совместный продукт их ассоциаций с сообществами микроорганизмов, главным образом микроскопическими грибами (S. Kusari с соавт., 2012). Российскими исследователями выполнен первый цикл работ по сравнительноему изучению содержания микотоксинов в злаковых и бобовых травах на производственных посевах и в естественной среде обитания (G.P. Kononenko с соавт., 2015; А.A. Burkin с соавт., 2017). В представленной работе мы впервые получили сведения о характере контаминации крестоцветных растений токсичными метаболитами микроскопических грибов, выявили различия в их локализации по вегетативным и генеративным органам, а также изменения, сопровождающие полный цикл развития. Целью нашей работы стало изучение состава и содержания токсичных метаболитов микроскопических грибов у горчицы белой (Sinapis alba L.) и оценка распределения этих веществ по органам растения. Объектами анализа были наземные части растений, отобранные в 2017 году с монопосева, а также их листья, стебли, цветки, стручки. Сбор осуществляли в следующие фазы: начало вегетации после завершении формирования базовой структуры растения, массовое цветение, образование зеленых стручков и полное созревание. Методом иммуноферментного анализа определяли содержание Т-2 токсина (Т-2), диацетоксисцирпенола (ДАС), дезоксиниваленола (ДОН), зеараленона (ЗЕН), фумонизинов (ФУМ), альтернариола (АОЛ), афлатоксина В $\mathrm{B}_{1}\left(\mathrm{AB}_{1}\right)$, стеригматоцистина (СТЕ), роридина А (РОА), циклопиазоновой кислоты (ЦПК), эмодина (ЭМО), охратоксина А (ОА), цитринина (ЦИТ), микофеноловой кислоты (МФК), PR-токсина (PR) и эргоалкалоидов (ЭА). У вегетирующей Sinapis alba в составе комплекса микотоксинов были найдены АОЛ, ЦПК, ЭА, а все остальные метаболиты отсутствовали или выявлялись спорадически. Весьма умеренное накопление микотоксинов в этом растении служит полезным хозяйственным признаком. Среди обследованных ранее злаковых и бобовых трав столь слабо контаминированных культур выявлено не было. В процессе вегетации горчицы состав микотоксинов и количественные соотношения между ними в целом сохранялись, но по мере ее созревания происходило снижение содержания АОЛ и ЦПК. Массовое цветение сопровождалось появлением в растении фузариотоксинов ДАС, ДОН, ФУМ, которые на следующей фазе (формирование стручков) уже не обнаруживались. В экспериментах с отдельными органами Sinapis alba были впервые установлены такие особенности, как множественная и интенсивная контаминация цветков с участием всех анализируемых микотоксинов, полное отсутствие фузариотоксинов в зеленых и спелых стручках, а также повышенное накопление АОЛ в листьях по сравнению со стеблями. Обсуждаются возможные причины этого явления, научная и практическая значимость новых сведений по степени контаминации, сезонной динамике и аккумуляции микотоксинов в этом растении, а также перспективы дальнейшего научного поиска.

Ключевые слова: горчица белая, Sinapis alba, микотоксины, T-2 токсин, диацетоксисцирпенол, дезоксиниваленол, зеараленон, фумонизины, альтернариол, афлатоксин В 1 , стеригматоцистин, роридин А, циклопиазоновая кислота, эмодин, охратоксин А, цитринин, микофеноловая кислота, PR-токсин, эргоалкалоиды, иммуноферментный анализ.

Сельскохозяйственные культуры, широко представленные на возделываемых угодьях и при этом часто встречающиеся в естественных ботанических формациях, в последние годы привлекают все большее внимание. Это связано не только с их хозяйственной значимостью, но и с высокой ценностью как экспериментальных объектов, позволяющих изучать особенности формирования биоценотических связей и экологического равновесия. Недавно российскими исследователями выполнен первый цикл работ, посвященных сравнительному изучению содержания микотоксинов в злаковых и бобовых травах на производственных посевах и в естественной среде обитания (1-3). Комплекс вторичных веществ в растениях все чаще рассматривается как совместный продукт их ассоциаций с сообще- 
ствами микроорганизмов, главным образом микроскопических грибов (4).

Культуры семейства Cruciferae (Brassicaceae), представленные в агробиоценозах многообразием родов и видов, в этом аспекте пока не обследованы. Наибольшую привлекательность среди них имеют однолетние растения, которые, наряду с высокой урожайностью и коротким вегетационным периодом, различаются по требованиям к почвам, устойчивости к засухе, понижению температур, болезням и вредителям. Эти растения применяют в качестве сидератов для предпосевной подготовки благодаря активной роли в формировании ценозов - улучшению качества почв и их обезвреживанию, в частности от загрязнения тяжелыми металлами (5).

Горчица белая (Sinapis alba L.) - однолетнее культивируемое растение, которое легко заселяет сельскохозяйственные угодья и естественные травостои, встречается на пустырях, у дорог, в огородах и садах. Его возделывают на семена для получения пищевого и технического масла, молодую зелень употребляют в пищу, посевы используют для выпаса, приготовления травяной муки, на силос, в ранние фазы до начала образования стручков травостои скашивают на корм скоту.

Последние годы отмечены крупными достижениями в селекции этой культуры, особенно благодаря развитию геномного подхода в оценке разнообразия гермоплазмы (6-9). Однако, несмотря на разностороннее использование, данные о вторичных метаболитах горчицы белой весьма ограничены. Так, в листьях и стеблях обнаружено присутствие ацетилхолина, в проростках - гистамина (10). Семена содержат витамины группы В, фитостеролы, ненасыщенные жирные кислоты и глюкозид синальбина (11), а также группы азот- и серосодержащих соединений - глюкозинолатов $(12,13)$. В процессе подробного анализа генетического аппарата описаны механизмы биосинтеза эруковой кислоты, глюкозинолатов, а также фитохелатина - фрагмента ( $\gamma$-Glu-Cys) $)_{\mathrm{n}}$-Gly пептидов, образуемого в результате реакции с участием фитохелатинсинтазы (ЕС 2.3.2.15) $(14,15)$. Каких-либо сведений о токсинообразующих свойствах микромицетов, колонизирующих эту культуру, а также о содержании в растении метаболитов грибов или образуемых in planta совместно с эндофитными грибами, в доступной литературе найти не удалось.

В представленной работе мы впервые получили сведения о характере контаминации крестоцветных растений токсичными метаболитами микроскопических грибов, выявили различия в их локализации по вегетативным и генеративным органам, а также изменения, сопровождающие полный цикл развития.

Целью нашей работы стало изучение состава и содержания токсичных метаболитов микроскопических грибов у горчицы белой и оценка распределения этих веществ по органам растения.

Методика. Объектами анализа были образцы вегетирующей горчицы, посеянной 28 мая 2017 года на опытном участке МСХА им. К.А. Тимирязева. Сборы материала начинали на 18-е и 25-е сут после посева по завершении формирования базовой структуры растения (I этап) и далее повторяли на 39-е и 41-е сут в фазу массового цветения (II этап), на 53-и и 58-е сут в фазу зеленых стручков (III этап) и на 67-е и 97-е сут при полном созревании (IV этап). Наземные части срезали на высоте 3-5 см от поверхности почвы. Начиная с 39-х сут после посева, растения разбирали на вегетативные (стебли, листья) и генеративные (цветки, стручки) органы с последующим анализом по тем же показателям. Образцы высушивали в затененном проветриваемом помещении, а затем измельчали на лабораторной мельнице. Для экстракции применяли смесь ацетонитрила и воды 
в объемном соотношении 84:16 при расходе 10 мл на 1 г навески. Экстракты после 10-кратного разбавления фосфатно-солевым буфером (pH 7,5) использовали для непрямого конкурентного иммуноферментного анализа.

Содержание микотоксинов - Т-2 токсина (Т-2), диацетоксисцирпенола (ДАС), дезоксиниваленола (ДОН), зеараленона (ЗЕН), фумонизинов (ФУМ), альтернариола (АОЛ), афлатоксина $\mathrm{B}_{1}\left(\mathrm{AB}_{1}\right)$, стеригматоцистина (СТЕ), роридина А (РОА), циклопиазоновой кислоты (ЦПК), эмодина (ЭМО), охратоксина А (OА), цитринина (ЦИТ), микофеноловой кислоты (МФК), PR-токсина (PR) и эргоалкалоидов (ЭА) определяли с помощью аттестованных коммерческих и исследовательских тест-систем (16). Нижний предел измерений соответствовал 85 \% связывания антител.

Данные представлены в виде среднего арифметического значения $M$ и ошибки выборочной средней \pm SEM, для статистической обработки использовали программу Microsoft Office Excel 2013 и непараметрический суммарный ранговый тест Вилкоксона с коррекцией непрерывности по $\mathrm{R}$ version $3.4 .3(17,18)$.

1. Встречаемость $\left(n^{+}\right)$и содержание микотоксинов (мкг/кг) в цельных растениях горчищы белой (Sinapis alba L.) при завершении формирования базовой структуры (I этап), массовом цветении (II этап) и образовании зеленых стручков (III этап) (г. Москва, 2017 год)

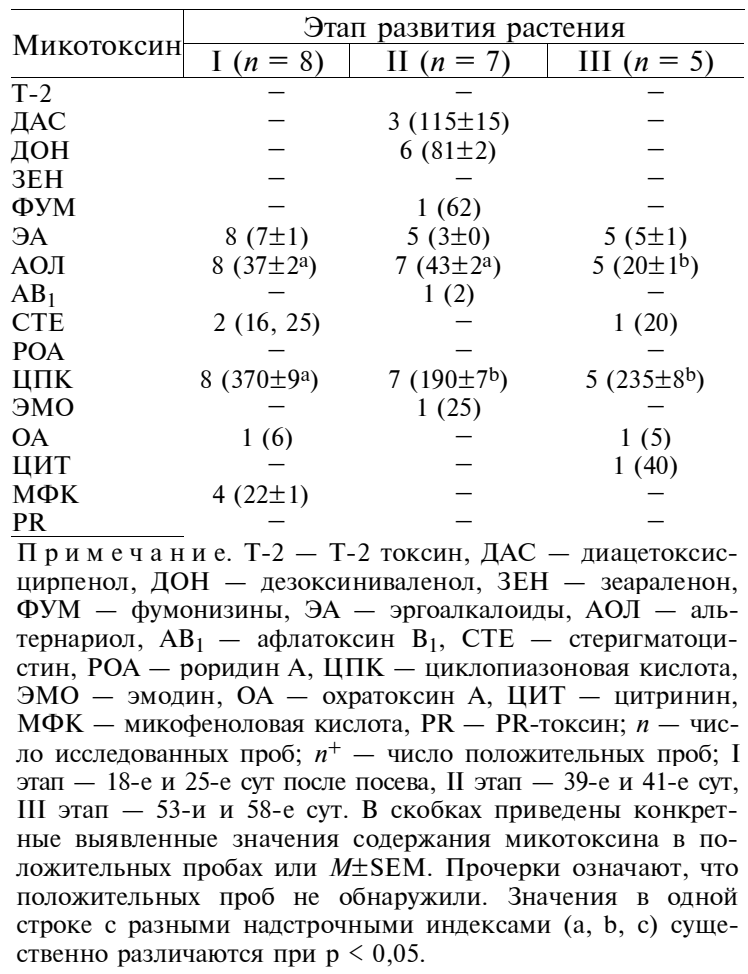

Результаты. В молодых растениях до начала цветения (I этап) регулярно выявляли 3 из 16 микотоксинов - ЦПК (сотни микрограммов на 1 кг), АОЛ и ЭА (в количествах на 1-2 порядка меньше) (табл. 1). МФК удалось определить лишь в половине образцов, СТЕ и ОА - в немногих случаях. Такое неравномерное обнаружение веществ, возможно, было связано с тем, что их концентрации находились вблизи порога чувствительности метода или оказывались вне диапазона измерений.

На II этапе (в фазу цветения) к ЦПК, АОЛ и ЭА добавились фузариотоксины ДАС, ДОН, ФУМ, а группу микотоксинов с фоновым содержанием пополнили $\mathrm{AB}_{1}$ и ЭМО в единичных образцах. Интересно, что редко выявляемые в начале вегетации СТЕ, ОА и МФК в цветущих растениях обнаружены не были. Среди фузариотоксинов доминировал ДАС, тогда как количество ДОН и ФУМ оказалось на порядок меньше. Подобное соотношение с преобладанием ДАС отмечали ранее у других объектов, но его причина пока остается неясной. В растениях с уже образовавшимися стручками (III этап) присутствовали те же три микотоксина - ЦПК, АОЛ, ЭА при редком выявлении СТЕ, ОА и ЦИТ. Статистическая обработка результатов показала, что в наземных частях горчицы в процессе вегетации наблюдалось достоверное $(\mathrm{p}<0,05)$ снижение содержания 
АОЛ и ЦПК, но в разные сроки (табл. 1). Количество ЦПК уменьшалось при зацветании и далее не изменялось, содержание АОЛ снижалось позже, на стадии образования стручков. Такая же тенденция в отношении ЦПК была отмечена нами ранее у дикорастущих злаковых трав к концу их вегетации в августе-сентябре (1).

В целом зеленая масса горчицы характеризовалась умеренным накоплением микотоксинов, что считается полезным хозяйственным признаком. Среди значительного многообразия обследованных ранее бобовых трав столь слабо контаминированных культур не выявляли (19). Этот показатель можно рассматривать как проявление устойчивости к грибным болезням, которую, наряду с высокой урожайностью, неприхотливостью к почвам, засухоустойчивостью и коротким вегетационным периодом, относят к критериям оценки перспективности однолетних масличных культур широкого применения. Степень накопления микотоксинов, по-видимому, становится результатом генетически отрегулированных отношений растения с микроскопическими грибами, определяющих внутреннюю микобиоту и специфический профиль вторичных метаболитов.

Присутствие во всех исследованных образцах трех контаминантов, возможно, указывает на то, что их появление вызывали эндофитные грибы. Судя по низкой степени накопления АОЛ и ЭА, среди этих грибов не было высокоактивных продуцентов или условия их обитания не способствовали интенсивным метаболическим реакциям. Значительное накопление ЦПК, которое может быть связано с инфицированием отдельными видами Aspergillus (20), не является особенностью горчицы: так же часто и в превосходящих количествах ее находили в других растениях (19). Нельзя исключать и того, что эти метаболиты были продуктами ассоциированного биосинтеза с участием грибов и растения.

Большинство возбудителей грибных болезней крестоцветных не относятся к числу продуцентов анализируемых веществ. Тем не менее обнаружение в этих растениях относительно большой группы фоновых микотоксинов может быть связано с токсигенными видами родов Penicillium, Aspergillus из числа так называемых вторичных грибов, сопутствующих комплексу патогенов. Среди немногих вредоносных заболеваний крестоцветных, которые могут быть причиной накопления микотоксинов, наряду с фузариозом следует отметить альтернариоз. По данным российских исследователей, среди патогенов обнаружено 9 видов феодиктиоспоровых гифомицетов, в том числе 5 видов рода Alternaria (включая A. tenuissima), а также грибы, относящиеся к комплексу A. infectoria (21). Участие мелкоспоровых токсигенных видов Alternaria может приводить к накоплению в растении АОЛ $(22,23)$, однако, судя по низкой концентрации этого метаболита без признаков явного варьирования при вегетации, его присутствие либо не связано с патогенными видами, либо активность продуцентов АОЛ ограничивается физиологическими особенностями культуры.

Чтобы составить представление о характере распределения микотоксинов в горчице белой и динамике их содержания в процессе развития, мы исследовали вегетативные и генеративные органы в разные периоды (табл. 2, 3). В фазу цветения (см. табл. 2) стебли и листья сохраняли признаки, свойственные молодым растениям 1-го сбора с той разницей, что в половине образцов листьев был обнаружен PR. Содержание АОЛ и ЦПК в листьях достоверно превышало $(\mathrm{p}<0,05)$ зафиксированное в стеблях. В цветках горчицы профиль микотоксинов оказался своеобразным: в нем были выявлены все вещества, кроме POA, при этом ДАС, ЦПК и PR обнаруживали в значительных количествах (сотни микрограммов на 1 кг). 
Важно отметить, что содержание МФК, СТЕ, $\mathrm{AB}_{1}$, ЭМО и PR, ранее отнесенных к группе фоновых микотоксинов, удалось измерить во всех образцах, а значит, оно попадало в диапазон определения. Среди вновь обнаруженных были ЦИТ, фузариотоксины Т-2 и ЗЕН. Очевидно, расширенный компонентный состав микотоксинов в зеленой массе горчицы, отмеченный в фазе цветения, был обусловлен в основном вкладом цветков при парциальном участии стеблей и листьев.

2. Встречаемость $\left(n^{+}\right)$и содержание микотоксинов $($ мКг/Кг) в органах растений горчищы белой (Sinapis alba L.) при массовом цветении (39-е и 41-е сут, II этап) (г. Москва, 2017 год)

\begin{tabular}{l|c|cc}
\hline \multirow{2}{*}{ Микотоксин } & \multicolumn{4}{|c}{ Органы растения } \\
\cline { 2 - 4 } & стебли $(n=4)$ & листья $(n=4)$ & цветы $(n=4)$ \\
\hline Т-2 & - & - & $4(2,8 \pm 0,3)$ \\
ДАС & - & - & $4(365 \pm 8)$ \\
ДОН & - & - & $4(170 \pm 10)$ \\
ЗЕН & - & - & $4(28 \pm 2)$ \\
ФУМ & - & - & $4(100 \pm 3)$ \\
ЭА & $3(6 \pm 2)$ & $3(4 \pm 2)$ & $4(5,8 \pm 0,8)$ \\
АОЛ & $4\left(18 \pm 1^{\mathrm{a}}\right)$ & $4(39 \pm 5 \mathrm{~b})$ & $4(77 \pm 8 \mathrm{c})$ \\
АВ & - & - & $4(3,3 \pm 0,3)$ \\
СТЕ & - & $2(14,14)$ & $4(26 \pm 3)$ \\
РОА & - & - & - \\
ЦПК & $4(40 \pm 8)$ & $4(250 \pm 29 \mathrm{~b})$ & $4(455 \pm 61 \mathrm{c})$ \\
ЭМО & - & - & $4(45 \pm 7)$ \\
ОА & - & - & $2(8,8)$ \\
ЦИТ & - & - & $4(39 \pm 2)$ \\
МФК & - & - & $4(33 \pm 6)$ \\
РВ & - & $2(100,115)$ & $4(335 \pm 42)$
\end{tabular}

П р и м е а н и е. Т-2 - Т-2 токсин, ДАС - диацетоксисцирпенол, ДОН - дезоксиниваленол, ЗЕН - зеараленон, ФУМ - фумонизины, ЭА - эргоалкалоиды, АОЛ - альтернариол, $\mathrm{AB}_{1}$ афлатоксин $\mathrm{B}_{1}$, СТЕ - стеригматоцистин, РОА - роридин А, ЦПК - циклопиазоновая кислота, ЭМО - эмодин, ОА - охратоксин А, ЦИТ - цитринин, МФК - микофеноловая кислота, PR - PR-токсин; $n$ - число исследованных проб, $n^{+}-$число положительных проб. В скобках приведены конкретные выявленные значения содержания микотоксина в положительных пробах или $M \pm S E M$. Прочерки означают, что положительных проб не обнаружили. Значения в одной строке с разными надстрочными индексами $(\mathrm{a}, \mathrm{b}, \mathrm{c})$ существенно различаются при $\mathrm{p}<0,05$; для различий в содержании АОЛ и ЦПК по органам р-значение составляло 0,02857 .

Появление в цветках фузариотоксинов могло быть следствием инфицирования грибами $F u$ sarium с участием комплекса токсигенных видов. Наряду с трихотеценами Т-2 и ДАС, свойственными грибам F. sporotrichioides и F. langsethiae, были выявлены ДОН и ЗЕН, характерные для $F$. graminearum, а также ФУМ, основными продуцентами которого считают $F$. verticillioides и $F$. proliferatum (24). Слабое накопление Т-2, ДОН, ЗЕН, ФУМ, а также отсутствие фузариотоксинов в листьях и стеблях могло быть связано с краткостью периода цветения и быстрым отторжением цветков. Однако для необычно высокого накопления ДАС в цветках горчицы (в среднем 365 мкг/кг), который на два порядка превышал количество Т-2, объяснений пока найти не удалось. Учитывая множественную контаминацию цветущих растений при выращивании на корм, целесообразно рекомендовать более ранние сроки скашивания.

На III этапе в стеблях, наряду с найденными ранее ЭА, АОЛ и ЦПК, выявляли $\mathrm{AB}_{1}$ и СТЕ. В листьях состав анализируемых веществ оказался шире и, помимо ЭА, АОЛ, ЦПК и $\mathrm{AB}_{1}$, включал ЭМО ЦИТ и МФК, из фузариотоксинов в части образцов был найден только ДОН (см. табл. 3). В зеленых стручках комплекс микотоксинов по общему числу детектированных веществ совпадал с их составом в листьях, но имел отличия по минорным компонентам: вместо ДОН и ЦИТ обнаруживали СТЕ и ОА.

Содержание АОЛ в стручках не отличалось от его количества в стеблях, но было ниже, чем в листьях, а содержание ЦПК оставалось таким же, как в листьях и стеблях. Редкое обнаружение или отсутствие фузариотоксинов в вегетативных органах (стебли, листья) и стручках указывает на препятствие их распространению по растению и может быть связано с недолгосрочностью периода цветения и быстрым отторжением цветков. На этой стадии развития содержание АОЛ в листьях оказалось 
достоверно выше $(\mathrm{p}<0,05)$, чем в стеблях и стручках, а в отношении ЦПК различий не наблюдалось.

3. Встречаемость $\left(n^{+}\right)$и содержание микотоксинов (мКг/кг) в органах растений горчицы белой (Sinapis alba L.) в фазу зеленых стручков (53-е и 58-е сут, III этап) и после их созревания (67-е и 97-е сут, IV этап)

\begin{tabular}{|c|c|c|c|c|c|}
\hline \multirow{2}{*}{ Микотоксин } & \multicolumn{3}{|c|}{ III этап } & \multicolumn{2}{|c|}{ IV этап } \\
\hline & стебли $(n=7)$ & листья $(n=3)$ & стручки $(n=8)$ & стебли $(n=18)$ & стручки $(n=19)$ \\
\hline $\mathrm{T}-2$ & - & - & - & - & - \\
\hline ДАС & - & - & - & - & - \\
\hline ДОН & - & $2(83,100)$ & - & - & - \\
\hline 3EH & - & - & - & - & $3(28 \pm 2)$ \\
\hline ФУМ & - & - & - & - & - \\
\hline ЭА & $6(10 \pm 2)$ & $2(2,4)$ & $6(3 \pm 1)$ & - & $1(2)$ \\
\hline АОЛ & $7\left(25 \pm 5^{a}\right)$ & $3\left(68 \pm 16^{\mathrm{b}}\right)$ & $8\left(30 \pm 4^{a}\right)$ & $7(69 \pm 24)$ & $6(40 \pm 5)$ \\
\hline $\mathrm{AB}_{1}$ & $2(2,2)$ & $3(3 \pm 1)$ & $3(2 \pm 0)$ & - & - \\
\hline CTE & $2(15,19)$ & - & $2(15,16)$ & $1(13)$ & $5(14 \pm 2)$ \\
\hline POA & - & - & - & - & - \\
\hline ЦПК & $7\left(205 \pm 37^{a}\right)$ & $3\left(220 \pm 91^{a}\right)$ & $8\left(275 \pm 31^{a}\right)$ & - & $18(140 \pm 7 b)$ \\
\hline ЭМО & - & $3(37 \pm 6)$ & $3(22 \pm 2)$ & $2(25,28)$ & $2(21,26)$ \\
\hline $\mathrm{OA}$ & - & - & $1(6)$ & - & $1(5)$ \\
\hline ЦИТ & - & $1(40)$ & - & - & $1(16)$ \\
\hline МФК & - & $1(26)$ & $1(26)$ & - & - \\
\hline PR & - & - & - & - & - \\
\hline \multicolumn{6}{|c|}{ 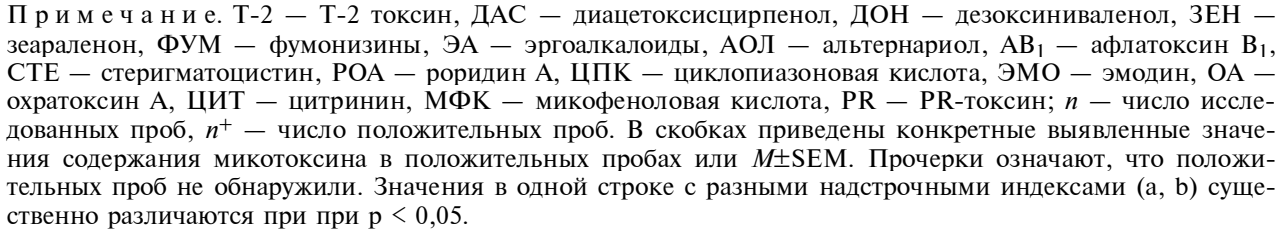 } \\
\hline
\end{tabular}

Ha IV этапе, судя по частичному обнаружению или отсутствию микотоксинов в стеблях и созревших стручках, контаминация растения в целом снизилась. АОЛ удалось обнаружить менее чем в половине проб, СТЕ и ЭМО - в редких случаях. В некоторых образцах стручков мы находили ЗЕН, ОА и ЦИТ в малых количествах, а в стеблях вообще не смогли обнаружить ЦПК и ЭА, которые определяли у зеленых растений. Тем не менее в пожелтевших спелых стручках содержание ЦПК удалось измерить во всех образцах, кроме одного. Ее количество существенно снизилось по сравнению с обнаруженным в зеленых стручках (p=0,000219) (см. табл. 3). Не исключено, что такое резкое уменьшение количества этого метаболита связано с подавлением функций эндофитных грибов или завершением жизненного цикла растения.

Интересно, что в первых экспериментах с подсолнечником и бобовыми растениями (клевер луговой, клевер белый, чина весенняя, донники, козлятник восточный, люпин многолистный), разделенными на листовые пластинки, стебли и цветки, нами также были выявлены закономерные различия, которые еще только предстоит оценить. Неравномерное распределение микотоксинов по растениям может быть следствием миграции как самих метаболитов, так и токсигенных грибов, а также результатом физиологических и метаболических контактов как внутри грибного сообщества, так и с организмом-хозяином. Интерпретация полученных результатов с точки зрения участия патогенных и эндофитных грибов во взаимовыгодном симбиозе с дифференциацией групп основного (конститутивного) и индуцируемого мутуализма позволит сделать следующий важный шаг в понимании механизмов взаимодействия высших растений и микроскопических грибов.

В целом зрелые стручки горчицы были крайне слабо контаминированы микотоксинами. Этот факт имеет важное практическое значение, 
поскольку ее семена в последние годы рассматриваются как уникальный и перспективный источник физиологически активных веществ. Так, в них был выявлен комплекс соединений, способных ингибировать образование опухолей, а также обладающих антибактериальным и антиоксидантным действием (25). Для продуктов гидролиза глюкозинолатов, в частности 4метилсульфанил-3-бутенил-изотиоцианата, экспериментально доказаны хемопротекторные свойства и способность подавлять процессы канцерогенеза (26). Отходы от отжима или экстракции семян при получении масла используются в кормлении животных, хотя жмыхи и шроты из горчицы рекомендуют применять с осторожностью из-за содержания простых нитрилов, образующихся при специфическом ферментативном гидролизе ряда глюкозинолатов (27). Изучение контаминации этого кормового сырья микотоксинами также имеет важное значение, поскольку на примере другой масличной культуры, подсолнечника, показаны существенные различия по составу токсикантов в семенах и продуктах их переработки и хранения (28).

В наших экспериментах для посевной горчицы белой была характерна тенденция к снижению содержания АОЛ и ЦПК по мере созревания растений. Учитывая то, что для сезонной динамики микотоксинов в бобовых травах, напротив, наблюдалось сохранение или возрастание их количества (19), весьма важным представляется микотоксикологическое обследование Sinapis alba из смесевых естественно сформированных сообществ.

В дальнейшем подобные проекты целесообразно реализовать и для других крестоцветных растений, которые считаются перспективными для внедрения в кормопроизводство и земледелие, таких как редька масличная (Raphanus sativus var. oleifera Metzg.), рыжик озимый (Camelina sp.), крамбе абиссинская (Crambe abyssinica Hochst.), рапс озимый (Brassica napus L. ssp. oleifera Metzg.), сурепица озимая (Brassica rapa L. ssp. oleifera automnalis) и других, а также дикорастущих представителей этого семейства.

Таким образом, у горчицы белой в условиях монопосева комплекс токсичных метаболитов микогенного происхождения представлен главным образом альтернариолом, циклопиазоновой кислотой, эргоалкалоидами и сохраняет устойчивость компонентного состава на всех фазах развития рстений. Для альтернариола и циклопиазоновой кислоты установлена преимущественная локализация в листьях в сравнении со стеблями, а цветки отличаются множественным характером контаминации с увеличением накопления метаболитов и присутствием фузариотоксинов. Снижение содержания циклопиазоновой кислоты в растении происходит в фазу массового цветения, альтернариола - на стадии образования зеленых стручков. Эти впервые полученные сведения и выявленные закономерности имеют важное значение для продолжения фундаментальных исследований, посвященных биологической роли грибных метаболитов в растениях, а также для разработки целесообразных мер профилактики интоксикаций, связанных с загрязнением пищевых продуктов, кормов и объектов окружающей среды микотоксинами.

\footnotetext{
${ }^{1}$ Всероссийский НИИ ветеринарной санитарии, гигиены и экологии - филиал ФГБНУ ФНЦ ВИЭВ РАН, 123022 Россия, г. Москва, Звенигородское ш., 5, e-mail: kononenkogp@mail.ru $\varangle$, aaburkin@mail.ru;

2ФГБОУ ВО РГАУ-МСХА им. К.А. Тимирязева, 127550 Россия, г. Москва, ул. Тимирязевская, 49, e-mail: mosina.1.v@yandex.ru

Поступила в редакцию 7 июля 2018 года
}

\section{THE FIRST MYCOTOXICOLOGICAL INVESTIGATION}




\title{
OF WHITE MUSTARD (Sinapis alba L.)
}

\author{
A.A. Burkin'1, G.P. Kononenko', L.V. Mosina ${ }^{2}$
}

${ }^{1}$ All-Russian Research Institute of Sanitary, Hygiene and Ecology - Branch of Federal Science Center Skryabin and Kovalenko All Russian Research Institute of Experimental Veterinary RAS, 5, Zvenigorodskoe sh., Moscow, 123022 Russia, e-mail kononenkogp@mail.ru ( $₫$ corresponding author), aaburkin@mail.ru;

${ }^{2}$ Timiryazev Russian State Agrarian University-Moscow Agrarian Academy, 49, ul. Timiryazevskaya, Moscow, 127550 Russia, e-mail mosina.1.v@yandex.ru

ORCID:

Burkin A.A. orcid.org/0000-0002-5674-2818

Kononenko G.P. orcid.org/0000-0002-9144-615X

The authors declare no conflict of interests

Received July 7, 2018

Mosina L.V. orcid.org/0000-0003-2120-0389

doi: 10.15389 /agrobiology.2019.1.186eng

\section{Abstract}

Crops widely represented on cultivated lands and often found in natural botanical formations have attracted increasing attention of researchers in recent years. This is due not only to their economic importance, but also to the high value of both experimental facilities that allow studying the features of the formation of the diversity of biocenotic connections and ecological equilibria. According to modern concepts, a complex of secondary substances in plants is increasingly seen as a joint product of their associations with microorganism communities, mainly microscopic fungi (S. Kusari et al., 2012). Recently, Russian researchers performed the first cycle of studies aimed at a comparative study of the content of mycotoxins in cereals and legumes in industrial crops and in the natural habitat (G.P. Kononenko et al., 2015; A.A. Burkin et al., 2017). In the present work, we obtained first information about the nature of the contamination of cruciferous plants with toxic metabolites of microscopic fungi, revealed for the first time differences in their localization in vegetative and generative organs, as well as changes accompanying the full development cycle. The aim of this work was to study the composition and content of mycotoxins in the white mustard (Sinapis alba L.), a cultivated plant of wide application, which also easily populates agricultural land and occurs in natural grass stands. For analysis, we used overground parts of plants and their organs (leaves, stems, flowers, pods) collected in the white mustard monoculture in 2017 during distinct phases of plant development. These phases were i) the beginning of the growing season after the completed formation of plant basic structure, ii) mass flowering, iii) the formation of green pods and iv) full ripening. The mycotoxins determined by the enzyme-linked immunosorbent assay were $\mathrm{T}-2$ toxin (T-2), diacetoxyscirpenol (DAS), deoxynivalenol (DON), zearalenone (ZEN), fumonisins (FUM), alternariol (AOL), aflatoxin $\mathrm{B}_{1}\left(\mathrm{AB}_{1}\right)$, sterigmatocystin (STE), roridin A (ROA), cyclopiazonic acid (CPA), emodin (EMO), ochratoxin A (OA), citrinin (CIT), mycophenolic acid (MPA), PR toxin (PR) and ergot alkaloids (EA). AOL, CPA, and EA were found in the mycotoxin complex of Sinapis alba organs during vegetation period, and all other metabolites were absent or detected sporadically. The very moderate accumulation of mycotoxins in this plant is a useful economic property, and previously no such slightly contaminated cultures were detected among examined cereals and legumes. During the vegetation of the mustard, the composition of mycotoxins and the quantitative ratios between them were generally stable, but the content of AOL and CPA decreased as the plant matured. Mass flowering was accompanied by the appearance in the plant of fusariotoxins DAS, DON, FUM, which were not detected in the next phase (pod formation). In experiments with individual organs of Sinapis alba, multiple and intense flower contamination with all analyzed mycotoxins, complete absence of fusariotoxins in green and ripe pods, as well as increased levels of AOL accumulation in leaves compared with stems are established for the first time. Possible causes of this phenomenon, the scientific and practical significance of new information on the degree of contamination, seasonal dynamics and accumulation of mycotoxins in this plant, as well as the prospects for further scientific research are discussed.

Keywords: white mustard, Sinapis alba, mycotoxins, T-2 toxin, diacetoxyscirpenol, deoxynivalenol, zearalenone, fumonisins, alternariol, aflatoxin $\mathrm{B}_{1}$, sterigmatocystin, roridin A, cyclopiazonic acid, emodin, ochratoxin A, citrinin, mycophenolic acid, PR toxin, ergot alkaloids, enzyme immunoassay.

\section{R E F E R E N C E S}

1. Burkin A.A., Kononenko G.P. Mycotoxin contamination of meadow grasses in European Russia. Agricultural Biology [Sel'skokhozyaistvennaya Biologiya], 2015, 50(4): 503-512 (doi: 10.15389/agrobiology.2015.4.503eng).

2. Kononenko G.P., Burkin A.A., Gavrilova O.P., Gagkaeva T.Yu. Fungal species and multiple mycotoxin contamination of cultivated grasses and legumes crops. Agricultural and Food Science, 2015, 24(4): 323-330 (doi: 10.23986/afsci.52313).

3. Burkin A.A., Kononenko G.P., Gavrilova O.P., Gagkaeva T.Yu. Mycotoxins in the legumes of natural fodder of the European Russia. Agricultural Biology [Sel'skokhozyaistvennaya Biologiya], 
2017, 52(2): 409-417 (doi: 10.15389/agrobiology.2017.2.409eng).

4. Kusari S., Spiteller M. Metabolomics of endophytic fungi producing associated plant secondary metabolites: progress, challenges and opportunities. In: Metabolomics. U. Roessner (ed.). In Tech, London: 2012, 241-266.

5. Seregin I.V. Uspekhi biologicheskoi khimii, 2001, 41: 283-300 (in Russ.).

6. Katepa-Mupondwa F., Raney J.P., Rakow J. Recurrent selection for increased protein content in yellow mustard (Sinapis alba L.). Plant Breeding, 2005, 124(4): 382-387 (doi: 10.1111/j.14390523.2005.01131.x).

7. Fu Y.B., Gugel R., Katepa-Mupondwa F. Genetic diversity of Sinapis alba germplasm as revealed by AFLP markers. Plant Genetic Resources, 2006, 4(2): 87-95 (doi: 10.1079/PGR2005100).

8. Klóska Ł., Cegielska-Taras T., Piętka T. Regeneration capacity of selected genotypes of white mustard (Sinapis alba L.). In Vitro Cell. Dev. Biol.-Plant, 2012, 48(2): 180-188 (doi: 10.1007/s11627-012-9432-5).

9. $\quad \mathrm{Fu}$ Y.B., Cheng B., Peterson G.W. Genetic diversity analysis of yellow mustard (Sinapis alba L.) germplasm based on genotyping by sequencing. Genet. Resour. Crop Evol., 2014, 61(3): 579-594 (doi: 10.1007/s10722-013-0058-1).

10. Roshchina V.V. Biomediatory $v$ rasteniyakh. Atsetilkholin $i$ biogennye aminy [Biomediators in plants. Acetylcholine and biogenic amines]. Pushchino, 1991 (in Russ.).

11. Golovkin B.N., Rudenskaya R.N., Trofimova I.A., Shreter A.I. Biologicheski aktivnye veshchestva rastitel'nogo proiskhozhdeniya [Bioactive substances of plant origin]. Moscow, 2001 (in Russ.).

12. Popova I.E., Morra M.J. Simultaneous quantification of sinigrin, sinalbin, and anionic glucosinolate hydrolysis products in Brassica juncea and Sinapis alba seed extracts using ion chromatography. J. Agric. Food Chem., 2014, 62(44): 10687-10693 (doi: 10.1021/jf503755m).

13. Vastenhout K.J., Tornberg R.H., Johnson A.L., Amolins M.W., Mays J.R. High-performance liquid chromatography-based method to evaluate kinetics of glucosinolate hydrolysis by Synapis alba myrosinase. Analytical Biochemistry, 2014, 465: 105-113 (doi: 10.1016/j.ab.2014.07.017).

14. Javidfar F., Cheng B. Construction of a genetic linkage map and QTL analysis of erusic acid content and glucosinolate components in yellow mustard (Sinapis alba L.). BMC Plant Biol., 2013, 13: 142 (doi: 10.1186/1471-2229-13-142).

15. Zhan X., Lui T., Duan M., Song J., Li X. De novo transcriptome analysis of Sinapis alba in revealing the glucosinolate and phytochelatin pathways. Front. Plant Sci., 2016, 7: 259 (doi: 10.3389/fpls.2016.00259)

16. GOST 31653-2012 Korma. Metod immunofermentnogo opredeleniya mikotoksinov. Moscow, 2012 (in Russ.).

17. The R project for statistical computing. Available http://www.r-project.org. No date.

18. McDonald J.H. Handbook of biological statistics. Available http://www.biostathandbook.com. No date.

19. Gavrilova O.P., Orina A.S., Gagkaeva T.Yu. Agrokhimiya, 2017, 11: 58-66 (doi: 10.7868/S0002188117110072) (in Russ.).

20. Chang P.-K., Ehrlich K.C., Fujii I. Cyclopiazonic acid biosynthesis of Aspergillus flavus and Aspergillus oryzae. Toxins, 2009, 1: 74-99 (doi: 10.3390/toxins1020074).

21. Levitin M.M., Gannibal F.B., Orina A.S., Gasich E.L., Khlopunova L.B., Baranova O.A. Immunologiya, allergologiya, infektologiya, 2010, 1(2): 112-113 (in Russ.).

22. Tralamazza S.M., Piacentini K.C., Iwase C.H.T., Rocha L.O. Toxigenic Alternaria species: impact in cereals worldwide. Current Opinion in Food Science, 2018, 23: 57-63 (doi: 10.1016/j.cofs.2018.05.002).

23. Ramires F.A., Masiello M., Somma S., Villani A., Susca A., Logriego A.F., Luz C., Meca G., Moretti A. Phylogeny and mycotoxin characterization of Alternaria species isolated from wheat grown in Tuscany, Italy. Toxins, 2018, 10(11): 472 (doi: 10.3390/toxins10110472).

24. Shi W., Tan Y., Wang S., Gardiner D.M., De Saeger S., Liao Y., Wang Ch., Fan Y., Wang Zh., Wu A. Mycotoxigenic potentials of Fusarium species in various culture matrices revealed by mycotoxin profiling. Toxins, 2017, 9(1): 6 (doi: 10.3390/toxins9010006).

25. Zielniok K., Szkoda K., Gajewska M., Wilczak J. Effect of biologically active substances present in water extracts of white mustard and coriander on antioxidant status and lipid peroxidation of mouse C2C12 skeletal muscle cells. J. Anim.Physiol. Anim. Nutr., 2016, 100(5): 988-1002 (doi: 10.1111/jpn.12412).

26. Abdull Razis A.F., De Nicola G.R., Pagnotta E., Iori R., Ioannides C. 4-Methsulfanyl-3butenyl isothiocyanate derived from glucoraphasatin is a potent inducer of rat hepatic phase II enzymes and a potential chemopreventive agent. Arch. Toxicol., 2012, 86(2): 183-194 (doi: 10.1007/s00204-011-0750-x).

27. Agerbirk N., Warwick S.I., Hansen P.R., Olsen S.E. Sinapis phylogeny and evolution of glucosinolates and specific nitrile degrading enzymes. Phytochemistry, 2008, 69(17): 2937-2949 (doi: 10.1016/j.phytochem.2008.08.014).

28. Burkin A.A., Ustyuzhanina M.I., Zotova E.V., Kononenko G.P. Reasons of contamination of production lots of sunflower (Helianthus annuus L.) seeds by mycotoxins. Agricultural Biology [Sel'skokhozyaistvennaya Biologiya], 2018, 53(5): 969-976 (doi: 10.15389/agrobiology.2018.5.969eng). 